\title{
Role of Perceived Social Support on Self-Esteem and Aggression among Adolescents
}

\author{
Amal Ibrahim Sabra' ${ }^{1}$, Lulah Abdelwahab Abdelaty Hassan ${ }^{2}$ \\ ${ }^{1}$ Assistant Professor of psychiatric and Mental Health Nursing Faculty of Nursing, Tanta University, \\ Egypt, ${ }^{2}$ Assistant Professor of Community Health Nursing, Faculty of Nursing, Tanta University, \\ Egypt
}

\section{Abstract:}

Adolescence period is a critical one in an individual's life. So, the need to study social support as a buffer against negative and psychological problems as aggression and as a key construct in increasing positive psychological outcomes as self-esteem is becoming urgent among adolescents. The aim of the study was to: explore the influencing role of perceived social support on self-esteem and aggression among adolescents. Study design: descriptive correlational study was used. Settings: This study was conducted at 7 preparatory and secondary governmental schools in Tanta City that were chosen randomly according to Tanta city districts. Subjects: The total number of the study sample was 500 students. It was obtained by multistage random sampling technique from the previously mentioned settings. Study tools: four tools were used; Tool I: Socio-demographic characteristics of the adolescents, Tool II: The Multidimensional Scale of Perceived Social Support (MSPSS), Tool III: Rosenberg Self-esteem Scale and Tool IV: The Buss-Perry Aggression Questionnaire (BPAQ). Results: results pointed out social support have a statistically significant positive role on enhancing self-esteem and reduction of aggression among studied adolescents. Conclusion \& Recommendations: adolescents who have proper social support are having high self-esteemed and less liable to develop aggression. So, programs that deal with adolescent self-esteem and aggression have to emphasize on the role of perceived social support.

Key words: Social support, Self-esteem, Aggression, Adolescent students 


\section{Tanta Scientific Nursing Journal}

\section{Introduction}

Adolescence is a term derived from the Latin word 'adolescere'. It means grow up or reach adulthood. This term symbolizes the period where adult attitude and behavioral patterns start to replace childish ones. Adolescence is unique, potentially stressful periods in which there are dramatic changes as marked physical, cognitive, emotional and social changes are experienced ${ }^{(1,2)}$. The rapid changes during adolescence can trigger inner conflicts or conflicts with adolescents' environments and as a result of such changes psychological wellbeing levels tend to decrease during this period. It is well documented that many mental health problems tend to emerge and can be predictive of occurrence of mental illness in later adulthood and with an estimated prevalence of psychiatric disturbance of about 15 - 20\%. Therefore, studying promoting factors for mental health of adolescence is becoming the major issue for nurses' studies ${ }^{(3,4)}$.

Of all the protective mental health factors of adolescence, studies presented that perceived social support plays a major role in lowering the incidence of adolescent mental health problems. Social support can be defined as the assistance available to an individual or a circle of an individual's life on which he or shecan rely upon whenever they need any assistance in social life. It also denotes having someone as family and friends during the time of crisis that enhance a sense of belongingness and the inner positive self-image ${ }^{(5,6)}$.The support and assistance can be in many forms as help in emotional support i.e. nurturance from closed ones, advice in form of the information, financial support, and sense of belongingness $^{(7,8)}$.

The potential positive influences of social support for individuals in different age groups have been demonstrated by research in the last two decades however, social support may be particularly important for adolescents. For adolescents, to solve problems concerning this transition period, adapt to their environment, keep themselves psychologically well and quietness transition from childhood to adulthood are obtained, perceived social support is imperative $(5,9)$. Furthermore, social support is generally linked to many benefits for adolescents 'mental health and it is a key construct in contribution to an individual's positive psychological outcomes such as self-esteem and the reduction of psychological problems 


\section{Tanta Scientific Nursing Journal}

such as aggression $^{(3,6)}$.

One important aspects of positive mental health among adolescence is self-esteem and it is crucial for the youths' mental health. Self-esteem is the extent to which individuals believe they are capable, significant, successful and worthy. Associations between low self-esteem and a variety of psychological problems among adolescents including criminal behavior, substance abuse, academic failure, as well as risky behaviors as aggression, sexual abuse, or being a member of gang ${ }^{(10,11)}$. Consequently, before reaching adulthood, it is imperative for the adolescent to develop high selfesteem. For that, possible associations of low or high self- esteem which are crucial during adolescence period have to be acknowledged. In this respect perceived social support is known as a virtual issue in enhancing and maintenance of selfesteem in adolescence since support from family, peers and significant others has negatively or positively influencing role on the development of adolescent's selfesteem $^{\cdot(10,11)}$. Hence, the influencing role of social support on adolescent selfesteem is an important area for research studies.

Today, one of the serious mental health problems which have captured the attention of many researchers among adolescents is aggression. It is well-recognized that, aggression is a major public health problem in the world. The use of aggression in achieving ones goals has become rampant among adolescents all over the world. Aggression is a term used to describe any behavior by an individual against another with the sole aim of inflicting pain (physical and psychological) ${ }^{(12,13)}$. Adolescence is being perceived as a period of "storm and stress" which predisposes them into more serious aggression and violence and higher vulnerability for future negative mental health outcomes $^{\cdot(4,6)}$. The prevalence of aggression is increasing in developing and developed countries. More specifically in Egypt the risk of aggression and criminal tendencies among adolescents is significant as stated by Wahdan etal. (2014) \& Elmasry etal., (2016). Given the high prevalence of aggression in Egypt and its dramatic consequences, studying factors that are influencing aggression among adolescents has become an increasing concern for promotion mental health of adolescence $^{(14,15)}$.

Literatures indicated that, perceived social support play a significant role to 
in adolescents' aggression. Social support from different sources, such as family members or peers can help buffer the effects of stressful events and support serves as a protective agent decreasing the possibility of the emergence aggression on adolescent development. It also has been linked in psychosocial and behavioral adjustment problems in the adolescent period like aggression. Indeed, for an adolescent to prevent aggressive behaviors and gain adaptive ones, it is crucial that $\mathrm{s} / \mathrm{he}$ be provided with social support to make changes in the psychological environment ${ }^{(3,16)}$.

\section{Significance of problem}

Adolescents constitute nearly $18 \%$ of the world's population. In Egypt, adolescents amount to nearly 20 million and consequently represent a substantial proportion of the country's human potential. Yet, despite the importance of adolescents as the future generation of adults, their mental health concerns receive less attention than other age groups. Therefore, considering the adolescence is a critical period in individual's life, the need to provide social support as a buffer against negative and psychological problems as aggression and as a key construct in increasing positive psychological outcomes as self-esteem is urgent.

The worldwide guidelines assure the vital role of nurses' in psychological health promotion especially with young people as they experience critical phase of life. Community mental health nurses work in a variety of settings, and are one of the largest groups of health care professionals who come into contact with adolescents. They are in the right place to enhance the psychological and emotional well-being of adolescents and to prevent the development of mental health problems by being aware of factors that can put adolescents at risk. As a result nurses have a golden chance and a unique opportunity to assess and enhance social supports of adolescents which it can boost their self-esteem and reduce aggressions and in turn results in psychological wellbeing.

\section{Aim of the study}

The aim of this study was to:-

Explore the role of perceived social support on self-esteem and aggressive behavior among adolescents.

\section{Research question}

- What is the role of perceived social support on both self-esteem and aggression among adolescents? 
Subjects and Method:-

\section{Research design}

Descriptive correlational study design was used.

\section{Setting of the study:-}

The study was carried out at preparatory and secondary governmental schools in Tanta city. Schools included in the study were 7 schools from total of 24 schools (3 secondary schools out of 9 , and 4 preparatory schools out of 15). According to Tanta districts, the study was carried out in east and west districts. The schools were chosen randomly according to each district and type of school.

\section{Subjects of the study:}

The total number of the study sample was 500 students (both sexes). The study subjects were obtained by multistage random sampling technique from the previously mentioned settings. The sample size was calculated using Epi-Info software statistical package created by World Health organization and Center for Disease Control and Prevention, Atlanta, Georgia, USA version $2002^{(17)}$. The criteria for sample size selection are $95 \%$ confidence limit and $80 \%$ power of analysis. The sample size was found at $\mathrm{N}>384$. To increase validity of the results it was increased to 500 .

\section{Exclusion criteria}

-Adolescent student who had psychiatric disorder and chronic medical disease was excluded from the study.

\section{Tool of the study}

A structured questionnaire schedule was developed by the researchers based on a thorough review of literatures (18-20). It consisted of four tools as follows:

\section{Tool I: Socio-demographic}

characteristics of the adolescent:

It developed by the researchers to illicit data about socio-demographic characteristics of studied subjects. .This part consisted of 9 items such as age, sex, grade of education, residence, parent's education and occupation, and family income.

\section{Tool II: The Multidimensional Scale of Perceived Social Support (MSPSS)}

The Multidimensional Scale of Perceived Social Support (MSPSS) was developed by Zimet etal $1988^{(18)}$. It was adopted by the researchers in this study. It is designed to measure perceptions of support from 3 sources: Family, Friends, and a Significant Other. This is 12 items answered on a 5-point Likert scale with response options ranging from 1 denotes very strongly disagree, 2 strongly disagree, 3 neutral, 4 strongly agree and 5 very strongly agree.

It classified into three subscales, each subscale composed of four items: -

(1) Family social support subscale: 
containing items such as "I can discuss my problems with my family", and "I get help and emotional support from my family'.

(2) Friends' support subscale: consisting of items such as " I have friends with whom I can share my happiness and pain", and "I can count on my friends when problems arise'.

(3) The significant other's support subscale: with items such as "I have a close person who can encourage me", and "I have a close person who supports me when I am in need'.

\section{Scoring system:-}

The total score of the scale ranged from 12 to 60 , a higher score refers to higher social support and the total score was classified as follows:

- $\quad$ Mild social support $\leq 36$.

- Moderate social support 37-48.

- High social supports 49-60.

\section{Tool III :The Rosenberg Self esteem Scale}

The Rosenberg self-esteem scale is most widely used self-esteem measure. It was developed by Rosenberg (1965) ${ }^{(19)}$. It was adopted by the researchers in this study. This is a 10-item measure of selfesteem answered on a 4-point Likert scale with response options ranging from strongly agree (0) to strongly disagree (3) for a possible range of 0 to 30 . High selfesteem is reflected by higher score.

\section{Scoring system:-}

The total score of self-esteem was classified as follows:

- Low self-esteem from 0 -10.

- Moderate self-esteem from $11-20$.

- High self-esteem from 21 -30.

\section{Tool IV: The Buss-Perry Aggression Questionnaire (BPAQ)}

The Buss-Perry Aggression Questionnaire was developed by Buss \& Perry (1992) ${ }^{(20)}$. It was adopted by the researchers in this study. The questionnaire composed of a 29 statements. The participants rate statements along a 5-point continuum from $1=$ "extremely uncharacteristic of me" to 5="extremely characteristic of me." The questionnaire consisted of four dimensions of aggression:

- Physical aggression (9 items): e.g. "If I have to resort to violence to protect my rights, I will").

- Verbal aggression (5 items): e.g. "I tell my friends openly when I disagree with them").

- Anger (7 items): e.g., "Some of my friends think I am a hothead".

- Hostility (8 items) e.g., "When people are especially nice to me, I wonder what they want". 


\section{Scoring system}

Overall score of the scale ranged from 29

to 145 and was categorized as the following:

- Mild aggression from $\leq 87$.

- Moderate aggression from 88- 116.

- High aggressions from $117-145$.

\section{Method}

1. An official permission letter to carry out the study was obtained from Dean of the Faculty of Nursing to manager of the settings of the study.

\section{Ethical considerations:}

- An informed consent of the studied subjects was obtained after appropriate explanation of the nature and purpose of the study.

- Anonymity and confidentiality of the collected data.

- The right to withdraw from the study at any time was assured.

- Nature of the study was not cause harm and/or pain to the entire sample.

3. Developing the tools: - Tool I was developed by researchers, tools II, III, and IV of the study were translated into Arabic language by the researchers and were tested for its face and content validity by five experts in the related fields and the necessary modifications were done.

4. The reliability of tools was tested by using the Cronbach's alpha (0.865,
0.974 and 0.87 ) for tools II, III, and IV respectively.

5. A pilot study was carried out on a sample of $10 \%$ of adolescents to ascertain the clarity and applicability of the study tool. In addition, it severed to estimate the approximate time required for the studied subject as well as to identify any obstacles that might be faced during data collection and these subjects were excluded later from the study.

\section{The actual study:}

- Collection of data for the present study was done during the period from February to May 2019. The average time for filling questionnaire of the study was approximately 15 to 20 minutes for studied subjects.

7. Researchers arranged with the headmasters of selected schools to meet with studied subjects in breaking time of school and then researchers distributed the questionnaire of the study on the individual basis and asked participants to fill it in the presence of the researchers for any clarification.

\section{Statistical analysis:}

The data were coded, entered and analyzed using SPSS (version 20). Descriptive statistics (frequency numbers and percentages) identified demographic characteristics and students responses to 


\section{Tanta Scientific Nursing Journal}

the questionnaire. Pearson's correlation was used to examine the correlations between social support, self-esteem and aggression. Linear regression was used to explore the prediction role of social support on self-esteem and aggression. Statistical significant was set at $\mathrm{P}$ value $<0.05 \%$ and highly significant at $\mathrm{P}<0.001$

\section{Results}

Table (1) presents distribution of the studied subjects according to their sociodemographic characteristics. The table showed that, $43.8 \%$ of the studied subjects was 12 +years and $17+$ years with Mean $15.948 \pm 2.609$ years and more than half $(54.8 \%)$ of the studied subjects were female. Regarding educational level, $(49.0 \% \& 51.0 \%)$ of studied subjects were belonged to preparatory and secondary education respectively and $74.0 \%$ of them lived in rural areas. Concerning father occupation of the studied subjects, $40.4 \%$ was professional and $30.4 \%$ had university education. In relation to mother education, about one third $(33.4 \%)$ of them had secondary education and most (74.6\%) of mother of studied subjects were house wives. About half (49.2\%) of the studied subjects reported that they had enough income.
Figure (1) shows distribution of the studied subjects in relation to levels of the Multidimensional Scale of Perceived Social Support (MSPSS). It is clearly observed that, more than half $(54.0 \%)$ of the studied subjects had moderate level of social supports followed by $38.8 \%$ of them had high social supports.

Figure (2) illustrates distribution of the studied subjects according to levels selfesteem. Findings reported that, $(65.8 \%)$ of the studied subjects had moderate level of self-esteem meanwhile only $4.6 \%$ of them had low level of self-esteem.

Figure (3) shows distribution of the studied subjects according to their levels aggression. It pointed out that, $64.2 \%$ of the studied students had moderate level of aggression followed by $30.4 \%$ had low level of aggression and only $5.4 \%$ had high level aggression.

Table (2) shows the correlation between total scores of social support with selfesteem, and aggression among the studied subjects. The table illustrated that, perceived social support had highly significant positive correlation with selfesteem ( $r=0.127, P<0.001)$ and highly significant negative correlation with total score of aggression $(\mathrm{r}=-0.123, \mathrm{P}<$ 0.001).This denotes that studied subjects who had high perceived social support are 
more likely to have high self -esteem and low aggression.

Table (3) describes the correlation between social support dimensions with self-esteem and aggression among the studied subjects. The table illustrated that, among perceived social support dimensions only family support dimension is significantly correlated with self-esteem and aggression. Family support dimension had positively correlation with self-esteem and negative significant correlation with aggressions.

Table (4) illustrates the prediction role of perceived social support on self-esteem and aggression among the studied subjects. It can noticed that perceived social support has a significant positive prediction role on self-esteem $(\mathrm{F}=8.188, \mathrm{P}=0.004)$. It also found that a significant negative effect for social support on aggression $(\mathrm{F}=18.508$, $\mathrm{P}=0.000$. This means perceived social support had significant positive role on enhancing self-esteem and reduction aggression among studied adolescents. 
Table (1): Distribution of The Studied Subjects According to Their Socio- demographic Characteristics

\begin{tabular}{|c|c|c|}
\hline \multirow[t]{2}{*}{ Socio-demographic characteristics } & \multicolumn{2}{|c|}{$\begin{array}{l}\text { Studied students } \\
\quad(\mathbf{n}=\mathbf{5 0 0})\end{array}$} \\
\hline & No & $\%$ \\
\hline $\begin{array}{c}\text { Age in years } \\
\qquad 12+\text { years } \\
\text { - } 15+\text { years } \\
\text { - } 17+\text { years } \\
\end{array}$ & $\begin{array}{c}219 \\
62 \\
219 \\
\end{array}$ & $\begin{array}{l}43.8 \\
12.4 \\
43.8\end{array}$ \\
\hline \multicolumn{3}{|c|}{ Mean $15.948 \pm 2.609$ years } \\
\hline $\begin{array}{ll}\text { Sex } & \\
\text { - } & \text { Male } \\
\text { - } & \text { Female } \\
\end{array}$ & $\begin{array}{l}226 \\
274\end{array}$ & $\begin{array}{l}45.2 \\
54.8\end{array}$ \\
\hline $\begin{array}{c}\text { Residence } \\
\bullet \quad \text { Rural } \\
\bullet \quad \text { Urban }\end{array}$ & $\begin{array}{l}370 \\
130\end{array}$ & $\begin{array}{l}74.0 \\
26.0\end{array}$ \\
\hline $\begin{array}{c}\text { Educational level } \\
\qquad \quad \text { Preparatory } \\
\text { - }\end{array}$ & $\begin{array}{l}245 \\
255\end{array}$ & $\begin{array}{l}49.0 \\
51.0\end{array}$ \\
\hline $\begin{array}{l}\text { Father education } \\
\text { - Illiterate /read and write } \\
\text { - Basic education } \\
\text { - Secondary } \\
\text { - University } \\
\text { Post - university }\end{array}$ & $\begin{array}{c}73 \\
82 \\
145 \\
152 \\
48\end{array}$ & $\begin{array}{c}14.6 \\
16.4 \\
29.0 \\
30.4 \\
9.6\end{array}$ \\
\hline $\begin{array}{l}\text { Father occupation } \\
\text { - Professional } \\
\text { - Employee } \\
\text { - Craft man } \\
\text { - Workers } \\
\end{array}$ & $\begin{array}{c}202 \\
78 \\
129 \\
91\end{array}$ & $\begin{array}{l}40.4 \\
15.6 \\
25.8 \\
18.2\end{array}$ \\
\hline $\begin{array}{l}\text { Mother education } \\
\text { - Illiterate /read and write } \\
\text { - Basic education } \\
\text { - Secondary } \\
\text { - University } \\
\text { - Post - university }\end{array}$ & $\begin{array}{c}142 \\
67 \\
167 \\
87 \\
37\end{array}$ & $\begin{array}{c}28.4 \\
13.4 \\
33.4 \\
17.4 \\
7.4\end{array}$ \\
\hline $\begin{array}{c}\text { Mother occupation } \\
\text { - House wives } \\
\text { - Professional } \\
\text { - } \text { Employee } \\
\text { - } \text { Workers } \\
\end{array}$ & $\begin{array}{c}373 \\
94 \\
16 \\
17 \\
\end{array}$ & $\begin{array}{c}74.6 \\
18.8 \\
3.2 \\
3.4 \\
\end{array}$ \\
\hline $\begin{aligned} \text { Income } & \\
- & \text { Enough and save } \\
- & \text { Enough } \\
\text { - } & \text { Not enough }\end{aligned}$ & $\begin{array}{c}202 \\
246 \\
52\end{array}$ & $\begin{array}{l}40.4 \\
49.2 \\
10.4\end{array}$ \\
\hline
\end{tabular}




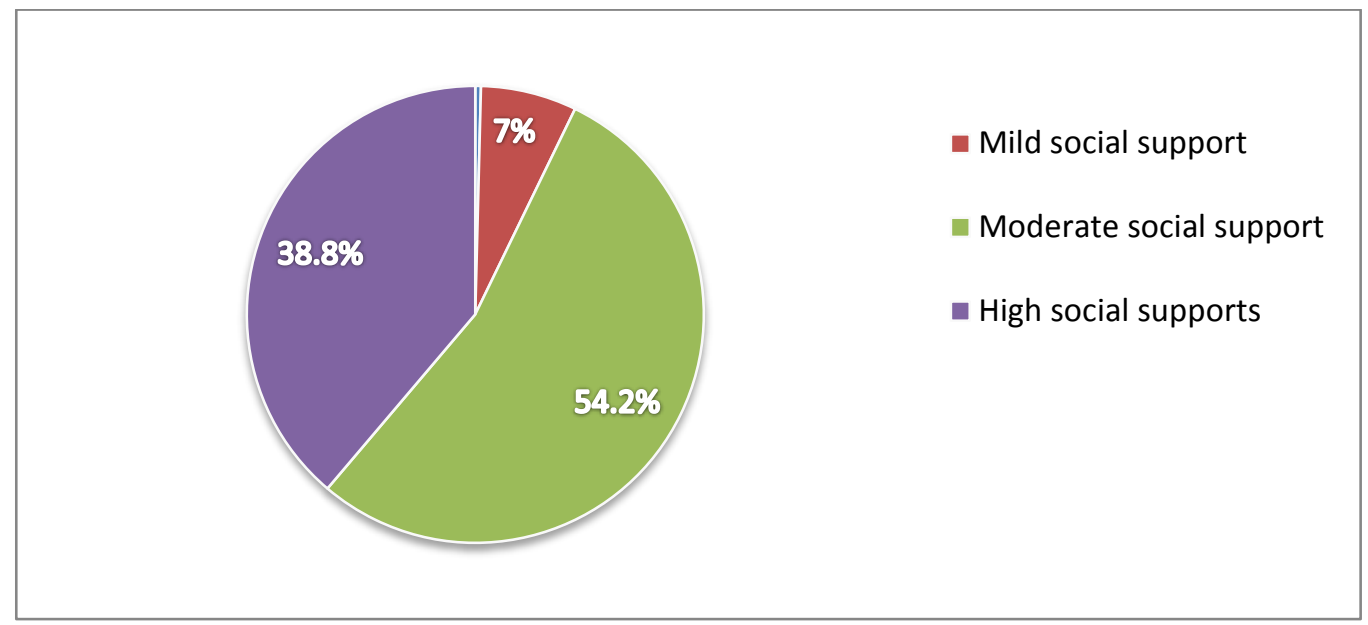

Figure (1) : Distribution of the Studied Subjects in relation to their Levels of Perceived Social Support

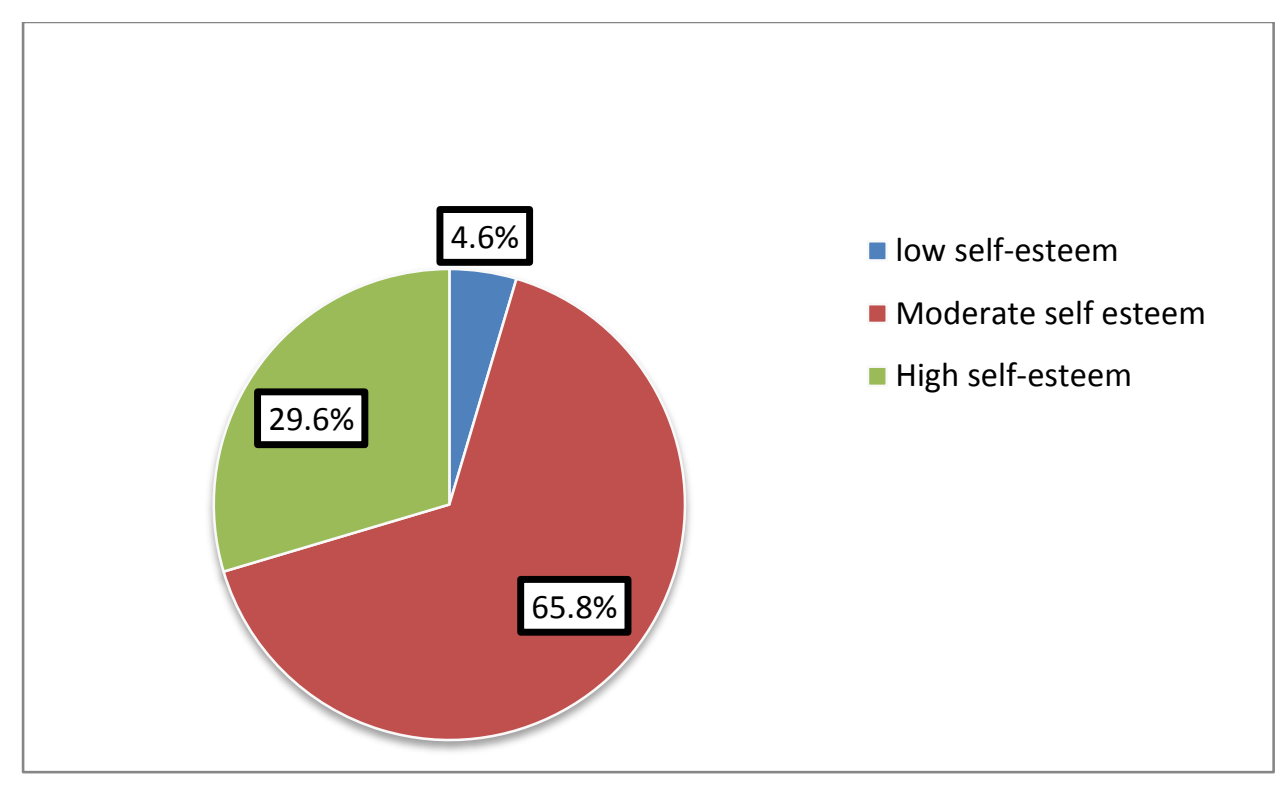

Figure (2):- Distribution of the Studied Subjects According to their Levels of SelfEsteem. 


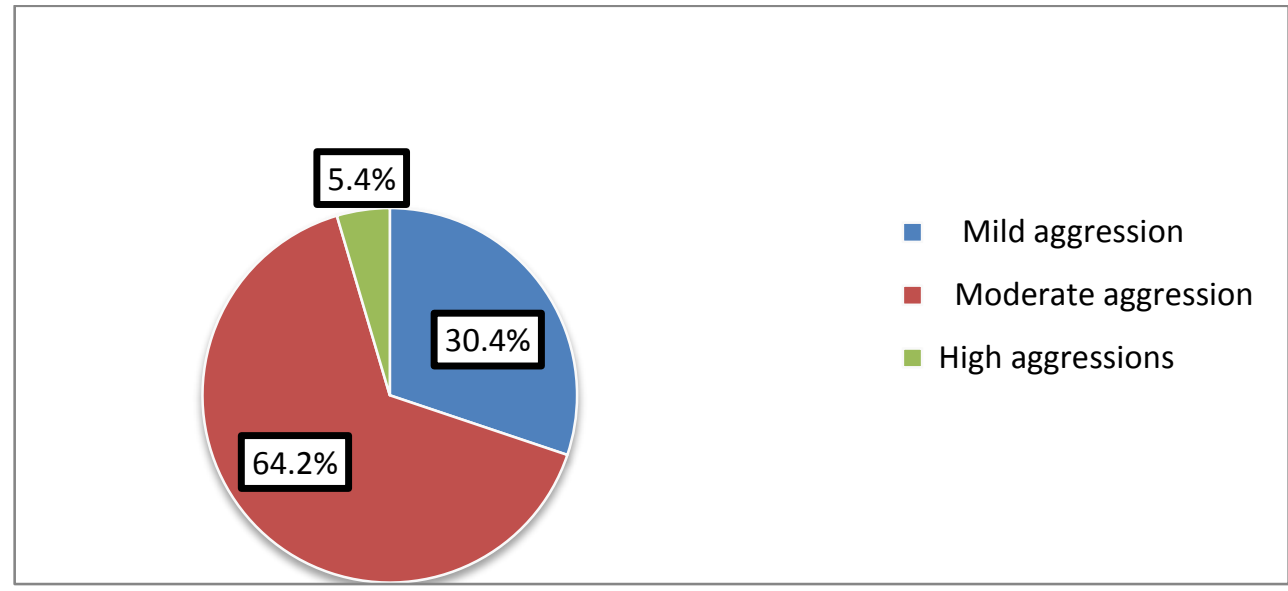

Figure (3):- Distribution of the studied Subjects according to their levels of aggression

Table (2): Correlation between Total Mean Scores of Perceived Social Support with selfesteem and Aggression among the Studied Subjects

\begin{tabular}{|l|c|}
\hline \multirow{2}{*}{ Variables } & Total score of social support \\
& $\mathbf{r}$ \\
& $\mathbf{p}$ \\
\hline \hline Total score Self-esteem & 0.127 \\
& $0.004^{* *}$ \\
\hline Total score of aggression & -0.123 \\
& $0.006^{* *}$ \\
\hline
\end{tabular}

**Highly Significant at $\mathrm{P}<0.001$

Table ( 3): Correlation between Perceived Social Support Dimensions with Self-esteem and Aggression among the Studied Subjects.

\begin{tabular}{|l|c|c|}
\hline \multirow{2}{*}{ Social Support Dimensions } & $\begin{array}{c}\text { Aggression } \\
\text { r }\end{array}$ & $\begin{array}{c}\text { Self-esteem } \\
\mathbf{r}\end{array}$ \\
\hline \hline Family social support & $\mathbf{P}$ & 0.154 \\
& -0.219 & $0.001^{* *}$ \\
\hline Significant persons social & $0.000^{* *}$ & 0.110 \\
support & 0.05 & $0.114^{*}$ \\
\hline Friends social support & 0.903 & 0.042 \\
& 0.69 & 0.346 \\
\hline
\end{tabular}

Table (4):- The prediction role of perceived social support on self-esteem and aggression among the studied subjects

\begin{tabular}{|l|c|c|c|c|c|c|c|c|}
\hline Variable & \multicolumn{4}{|c|}{ Self-esteem } & \multicolumn{4}{c|}{ Aggression } \\
\hline $\begin{array}{l}\text { Social } \\
\text { support }\end{array}$ & $\mathrm{AR}^{2}$ & $\mathrm{~F}$ & $\beta$ & $\mathrm{P}$ & $\mathrm{AR}^{2}$ & $\mathrm{~F}$ & $\beta$ & $\mathrm{P}$ \\
\cline { 2 - 9 } & 0.014 & 8.188 & 0.127 & $0.004^{* *}$ & 0.034 & 18.508 & -.189 & $0.000^{* *}$ \\
\hline
\end{tabular}

**Highly Significant at $\mathrm{P}<0.001$ 


\section{Tanta Scientific Nursing Journal}

\section{Discussion}

Perceived social support assists adolescents to promote a sense of trust and enables them to cope with this critical period more healthily. Perceived social support is a key factor in helping adolescents navigates the major life changes and a key construct in increasing positive psychological outcomes ${ }^{(5,21)}$.

Data of the present study could answer the research question of the study that perceived social support has significantly positive correlation with self-esteem and negative correlation with aggression and perceived social support had statistically significant positive role on enhancing selfesteem and reduction of aggression among studied adolescents.

Self-esteem could be said to be an attitude towards oneself along positive or negative dimensions. It could also see as the subjective evaluation of self in in relation to social networks belongings to. In line with that, significant influencing role of perceived social support on enhancing selfesteem may be justified $(8,21)$. From researcher's opinion, adolescents can formulate their thoughts, feelings and experiences they had through interaction with others around them then in the shadow of these formulated experiences, they judge and evaluate themselves positively or negatively. In other meaning, perceived acceptance, empathy, emotional warmth, respect, attention and nonjudgmental from social support can lead adolescents to feel good about themselves and paint positive portray for themselves which form a fertile environment for development and enhancing their self-esteem. In the same line of rationalization, an adolescents whose self-esteem is low believes that, important people who for them do not love and appreciate him/her as consequently leading to feelings of being neglected, rejected, insecurity, and uncertainty, which in turn, they capsulated these negative perceptions toward themselves into low self-esteem. Alongside with this justification Wang etal., (2018) stated that interactions with others influence and may determine the way adolescents perceive themselves in relation to others, their attitudes, and their behaviors. ${ }^{(22)}$

This result is consistent with previous research results conducted on these constructs. Kumar, etal., (2014) assessed the multidimensional perceived social support and self-esteem among 100 school students, the study has revealed that, there is statistically a positive relationship between the social support that a person received through various sources and selfesteem that in turn influences the selfesteem $^{(3)}$. Additionally, Tahir etal (2015) 
in an influential study examined the impact of perceived social support on self-esteem found out that, individuals with high selfesteem are more likely to have more social support ${ }^{(23)}$. Another study conducted by Bhat (2017) to evaluate the relationship of social support with self-esteem among adolescents' students and concluded that, self-esteem is influenced mainly by social support and adolescents who are receiving good social support from various sources are having better view of themselves ${ }^{(11)}$. Adolescents are more susceptible to aggression. It stem from various stressors faced them. When faced with these stressors, adolescents who have social support from different sources of support as parents, teachers, peers, and schools will seek advice easily, feedback, and solutions to cope such stressors ${ }^{(2,4)}$. In the same line, the result of present study revealed perceived social support has statistically significant positive role on the reduction of aggression among studied subjects .From perspective of researcher this result may be justified as when adolescent feels overwhelmed by stress, he /she tend to use aggressive behavior in dealing with situations. In case of presence of social support that means, presence of someone who can provide assistance, or someone who can touch on adolescent's shoulders at times of stressful situations or presence of a reliable one at times of stress. As result of this adolescent experience emotional security and containment, feel less threatened, appraise and cop with situation healthy and consequently less need to have aggression.

Similar findings linking perceived social support and aggression have been documented in the national and international scientific researches that included adolescent participant samples. At the national level, Elmasry etal., (2016) conducted study on Egyptian adolescent involvement in violent behavior ,the findings were thirty-one percent of adolescents reported being involved in a physical fight and social support was selected as the most predictors linked with reducing aggression by studied adolescents $^{(14)}$. Another Egyptian study conducted by Ali et al (2018) to assess the effect of social skill training program on aggression among adolescents in residential institutions in Port-Said City. They found that the social skills training program has a positive effect of decreasing $\operatorname{aggression}^{(24)}$.

At the international level, a study was done by Samadifard \& Damirchi (2018) on social support and aggression. The study found that, social support sources positively affect the individual's adaptation in a positive way and aggressive 


\section{Tanta Scientific Nursing Journal}

expression has been linked to reduced social support ${ }^{(25)}$.

For better and for worse, family support play a central role in shaping an individual's psychological make-up across the life course. The current study indicated the correlation was high with only family dimension of social support with both selfesteem and aggression. On other words through the results it can be seen that among the dimension of perceived social support family has significant positive influencing role on both self-esteem and aggression among studied subjects. Reasoning for this result from researcher 's view may be related to, the family is the first and foremost attribute since the birth day of the person where the person's selfesteem is shaped and feels very much secured being close contact to the family. Specifically, the result may be largely due to the nature of Egyptian family. Egyptian family is characterized by cohesion natures, warming ties, affection, flexibility and kindness between their members. In Egyptian family even family member become adolescent, adult or even married is still emotionally supported by his /her family and the influence of the family on the individuals has not weakened. For some instance, family provides financial assistance to its member's even he/she is married and departs from the family.
Therefore, Egyptian family is still basic and fundamental social unit support in all stages of life that fosters the stability, wellbeing and sustainability of its members. So, it is not surprising for the researcher that family has the most influencing role on both self-esteem and aggression as reported by studied adolescence rather than friends and significant others.

Another important justification may be attributed to the nature of the study setting; the current study was conducted at Tanta city. It is a city lies at midway between civil and rural life. This city still colored by taste of rural life that characterized by strong ties and cohesive among family members and preferred the concept of extended family that participants can find support from more than one members of the family as uncle, aunt or grandmothers. This may be supported by most of the studied adolescents in the current study lived in rural area. Additionally, the sociodemographic characteristics of the studied subjects pointed that most of mothers of participants were house wives who may have more time to take care and listen to their young than worked mother. Another justification to this result, most parents of the studied subjects were educated either secondary or university. Educated parents may be have knowledge and awareness about how to treat adolescents and cope 
effectively with challenges of adolescence period that in turn lead to adolescent feels secure and crosses this period psychologically well .

This result is supported by study done by Bibi \& Malik (2016) who found that, those adolescents who trust their families and have strong relationship with them have been observed to rank it as first source of social support. ${ }^{(26)}$. Indeed, Wang \&Zhou (2016) revealed that, the continuity of family connections and a secure emotional base is crucial for the positive development of young people and protective factors against a range of health risk behaviors. ${ }^{(27)}$.

\section{Conclusion}

This study is focused on the young population and provides an insight of importance of social support for selfesteem and aggression. Based on the current resultss, it can be concluded that, perceived social support has highly positive significant correlation with selfesteem and a negative significant correlation with aggression and play vital positive influencing role in enhancing selfesteem and reduction of aggression among studied adolescents.

\section{Recommendation}

1- Nurses working with the adolescent population at different settings need to boost their self-esteem and enhance their social support circles.

2- Educational and counseling programs for supportive system of adolescent in particular family about psychological challenges and needs of adolescent especially aggression and self-esteem

3- Community mental health nurse should encourage adolescents to negotiate their emotions and problems with supportive ones in particular the family, as it is valuable for mental health and avoidance of aggression.

\section{Reference}

1- Zhao J, Wang, Kong F. Exploring the mediation effect of social support and self- esteem on the relationship between humor style and life satisfaction in Chinese college students. Personality and Individual Differences. 2014; 64, 126-130.

2- Savi Çakar F, Tagay O. The mediating role of self-esteem: The effects of social support and subjective well-being on adolescents' risky behaviors. Educational Sciences: Theory \& Practice 2017;17 (3):859876

\section{3- Kumar R . Lal R, Bhuchar V.} Impact of social support in relation to self-esteem and aggression among adolescents . International Journal of 
Scientific and Research Publications, 2014;4( 12):ISSN 2250-3153.

4- Triana $\mathbf{R} \quad \& \quad$ Keliat $\mathbf{B}$.The relationship between self-esteem, family relationships and social support as the protective factors and adolescent mental health. Humanities \& social sciences reviews. 2019;7(1): 41-47.

5- Muna S, Jamal M, Al Khateeb KA. Comparison of social support among adolescents with and without visual impairments in Jordan: a case study from the Arab region. Journal of Visual Impairment \& Blindness. 2014;8 (3):667- 775.

6- Mobasheri M, Yousefi Z, Moradi A, Mirzaeian R. Exploring the effect of social support and religious beliefs on the life satisfaction among the elderly living in Borujen. Life Science Journal. 2014;11(9):459-464.

7- Alorani O, Alradaydeh M. Spiritual well-being, perceived social support and life satisfaction among university students. International Journal of Adolescence and Youth. 2018; 23(3):889-99.

\section{8- Veselska Z, Madarasova A,} Gajdosova B. Socio-economic differences in self-esteem of adolescents influenced by personality, mental health and social support.
European Journal of Public Health. 2017; 20(6): 647-652.

9- Salami OS. Moderating effects of resilience, self-Esteem and social Support on adolescents' reactions to violence. Asian Social Science. 2010; 6 (12): 1124-1134.

10- Ikiz F, Cakar F. Perceived social support and self-esteem in adolescence. Social and Behavioral Sciences. 2010; 5, 2338-2342.

11-Bhat SA. The relationship of perceived social support with selfesteem among college-going students. International Journal of Advanced Research and Development. 2017; 2(3): 308-310.

12-Collins N, Emmanuel E. Effects of Self-esteem and Gender on Aggressive Behavior among Adolescents, Journal of Psychology. 2017; 8(2):61-67.

\section{3- Mansour HA, Dardas L, Nawafleh}

H, Abu-Asba M. Psychosocial predictors of anger among university students. Children and Youth Services Review. 2012; 34(2): 474-479.

14- Elmasry N, Fouad A, Khalil D, Sherra K. Physical and verbal aggression among adolescent school students in Sharkia, Egypt: prevalence and risk factors. Egyptian journal of psychiatry. 2016; 137(3):166-173.

15- Wahdan N, El-Nimr R, Wahdan A. 
Risk of aggression and criminal behavior among adolescents living in Alexandria Governorate, Egypt, Eastern Mediterranean Health Journal. 2014; 20(4):265-72.

16- Jun W, Lee G. Comparing anger, anger expression, life stress and social support between Korean female nursing and general university students. Journal of Advanced Nursing. 2017; 73(12):2914-2922.

17-Andrew G. Introduction to Epi Info 2002.

18- Zimet GD, Dahlem NW, Zimet SG, Farley GK. The Multidimensional Scale of Perceived Social Support. Journal of Personality Assessment. 1988;52:30-41

19- Buss AH, Perry, MP. The Aggression Questionnaire. Journal of Personality and Social Psychology. 1992; 63, 452459.

20-Rosenberg M. Society and the adolescent self-image. Princeton, NJ: Princeton University Press. 1965 (Chapter 2 discusses construct validity.)

21- Dudnx G, Zehra F, Tekgöz A. The relationship between types of humor and perceived social support among adolescents. Social and Behavioral Sciences. 2014; $152.1194-1200$.

22- Wang J, Mann F, Evans L, and Johnson S. Associations between loneliness and perceived social support and outcomes of mental health problems: a systematic review. BMC Psychiatry.2018; 18 (1):156-17.

23-Tahir WB, Inam A, Raana $T$. Relationship between social support and self-esteem among adolescent girls. Journal of Humanities and Social Science. 2015; 20(2):42-46.

24-Ali SI, Abdel-Fatah SR, Mahmoud AS, El-Sayad MS. Effect of social skill training program on self-esteem and aggression among children in residential institutions in Port-Said City. Port said scntific journal of nursing .2018; 5(2): 105-123.

25- Samadifard H, Damirchi E. The relationship between perception of social interaction, perceived social support and social acceptance with aggression among adolescents. Journal of Research and Health. 2018; $8(1): 38-46$.

26-Bibi N, Malik JA. Effect of social support on the relationship between relational aggression and familymaladjustment: Adolescents' perspective. Pakistan Journal of Psychological Research. 2016; Vol. 31, No. 1, 63-76.

27-Wangi Q, Zhou T. The impact of family functioning and mental health condition on the child's behavioral problems. International Journal of Social, Behavior and Personality.2015; 42 (7):556-570. 